\title{
6. Applied Law Schemes and Responsible Government: Some Issues
}

\author{
Joe Edwards
}

\section{Introduction}

An 'applied law scheme' is a type of cooperative legislative scheme in which one jurisdiction enacts a model law which is then 'picked up' or 'applied' by another jurisdiction or group of jurisdictions. In the 1990s, applied law schemes were the 'next big thing' in Australian federalism; a way of achieving that hallowed goal, uniformity of regulation across the nation, in circumstances where there was no political will, or constitutional power, for the enactment of a Commonwealth law. But then, in $R v$ Hughes, ${ }^{1}$ the High Court raised serious questions about the constitutional validity of the most significant applied law scheme, the Corporations Law scheme, and it seemed as though applied law schemes were, if not consigned to the dustbin of history, then at least of considerably less utility than we had thought. If regulatory uniformity was to be achieved, we were going to have to opt for a cooperative legislative scheme that was either significantly 'tighter' or significantly 'looser' than an applied law scheme.

At the 'tighter' end of the spectrum are what we call 'reference schemes', where the States refer a 'matter' to the Commonwealth Parliament under s 51(xxxvii) of the Constitution, and the Parliament then enacts a law with respect to that matter. This, of course, is how we ended up with the Corporations Act 2001 (Cth), which superseded the Corporations Law scheme; and there have been other references of matters in the past decade, in areas such as personal property securities, consumer credit, business names, de facto financial matters and terrorism. However, it hardly need be said that reference schemes are treated with caution by the States, for the simple reason that they achieve regulatory uniformity by the transferral of legislative power to the centre. They are thus not a means of achieving regulatory uniformity except in those relatively rare cases where the need for uniformity, or the speed with which it must be attained, is (perceived to be) especially great. ${ }^{2}$

1 (2000) 202 CLR 535 ('Hughes').

2 See, on this point, G Williams, 'Cooperative Federalism and the Revival of the Corporations Law: Wakim and Beyond' (2002) 20 Company and Securities Law Journal 160, 168. 
At the 'looser' end of the spectrum are what we call 'mirror law schemes', which involve the Commonwealth and the States and Territories (or simply the States and Territories) enacting legislation in relation to an area in the same, or substantially the same, terms. Examples of the mirror law schemes include the uniform defamation Acts, the uniform evidence Acts, the succession or wills Acts and the new work health and safety Acts. However, while mirror law schemes (generally) do not raise the same constitutional issues which, after Hughes, were thought to beset applied law schemes, nor present the same challenge to State 'independence' or 'autonomy' as presented by reference schemes, they also (generally) fail to achieve the kind of regulatory uniformity to which our policy makers aspire. As Chief Justice Robert French has put it, mirror law schemes create not 'one law covering the whole country', but 'a mosaic of similar laws'. ${ }^{3}$

However, despite the dismay that greeted the collapse of the Corporations Law scheme - despite the sense in many quarters that reference schemes or mirror law schemes were the way things were going to have to be - applied law schemes never really went away. While the Commonwealth and the States scrambled to organise the State references upon which the Corporations Act is based, the applied law schemes regulating less high profile areas - like agricultural and veterinary chemicals, electricity and therapeutic goods and poisons - hummed along quietly in the background.

Moreover, in the past five years or so, applied law schemes have proliferated faster than any other type of cooperative legislative scheme. Indeed, it would not be too much of an exaggeration to say that they have become the default way that the Commonwealth and the States and Territories seek to achieve regulatory uniformity.

Some of the new applied law schemes involve legislation enacted by the Commonwealth and the States and Territories. These include, for example, the applied law schemes regulating:

- consumer protection;

- gas;

- energy retail; and

- commercial shipping.

Others, however, involve legislation enacted only by the States and Territories (although the Commonwealth has often been a party to the intergovernmental agreement underpinning the scheme, and has played an important role in funding). Examples of these schemes include those for the regulation of:

3 See Justice R S French, ‘Horizontal Arrangements: Competition Law and Cooperative Federalism’ (2008) 15 Competition and Consumer Law Journal 255, 261, referring to the Uniform Companies Scheme, which operated in Australia between 1961 and 1981. 
- health practitioners;

- early childhood education and care;

- occupational licensing;

- railways;

- co-operatives; and

- heavy vehicles.

The schemes just mentioned are only those that are already operational, or at a relatively advanced stage of development. But there are others in the works, not least of which is the proposed applied law scheme for the regulation of the legal profession.

The purpose of this chapter is two-fold. First, it will offer a primer on just what an applied law scheme is and the way in which one works. Secondly, it will explore some of the challenges posed by applied law schemes to the system of responsible government established by, and underpinning, the Constitution. In other words, it asks the question: does the use of an applied law scheme to achieve regulatory uniformity result in us all paying too high an accountability price?

\section{What is an applied law scheme?}

\section{The starting point: An intergovernmental agreement}

The starting point for most applied law schemes, particularly in recent times, has been an intergovernmental agreement in which the various interested jurisdictions - either the Commonwealth and the States and Territories, or just the States and Territories - agree that a particular area requires regulatory uniformity. The Council of Australian Governments (COAG) has often been the forum at which these agreements are made, but this is not necessarily the case. The Standing Council on Law and Justice (SCLJ) (formerly the Standing Committee of Attorneys-General (SCAG)) has also been responsible for the implementation of several high profile cooperative legislative schemes (although it has tended to favour mirror law schemes - such as the uniform defamation Acts and the uniform evidence Acts - rather than applied law schemes).

An intergovernmental agreement may, of course, deal with any matter to which the parties turn their minds. However, in the ordinary course of things, it will deal with the following issues:

- the general content of the scheme (that is, the matters that it will regulate and the manner in which it will do so); 
- governance of the scheme (including, in many cases, the establishment of a Ministerial Council constituting the responsible Ministers of the relevant jurisdictions);

- division of costs between the jurisdictions (both during the transition phase and subsequently);

- timelines for the establishment of the scheme;

- reporting and accountability;

- dispute resolution; and

- withdrawal from the scheme.

Once an intergovernmental agreement has been made, it will then be up to the bureaucracies of the Commonwealth and States and Territories - policy officers, government lawyers and drafters - to make the necessary arrangements for the implementation of the applied law scheme.

\section{Basic operation of an applied law scheme}

Put simply, an applied law scheme works as follows:

- one jurisdiction (usually called the 'host jurisdiction') enacts a model law in its jurisdiction (usually as a Schedule to an Act of Parliament and, in recent times, usually called a 'National Law'); and then

- each other jurisdiction (usually called a 'participating jurisdiction') enacts an Act (an 'application Act') which applies the National Law in its jurisdiction (and, more particularly, in the 'gap' in the 'reach' or 'coverage' achieved by the exercise of legislative power of the host jurisdiction).

When the Commonwealth is the host jurisdiction (which is not always the case), it will obviously be limited to making a law which is supported by a head of legislative power. ${ }^{4}$ So, for example, the Commonwealth could rely on the Territories power in s 122 of the Constitution to make a law applying only in the Australian Capital Territory (ACT). The States and the Northern Territory (NT) could then apply the law in the 'gap' left by the Commonwealth's exercise of legislative power - that is, outside the ACT - thus ensuring a nationwide regulatory scheme. This was how the old Corporations Law scheme worked. And it remains the way in which agricultural and veterinary chemicals are regulated. ${ }^{5}$

\footnotetext{
4 The Commonwealth Parliament may, of course, make laws only with respect to certain, discrete subject matters, such as interstate and overseas trade and commerce (s 51(i) of the Constitution), taxation (s 51(ii)), foreign, trading and financial corporations (constitutional corporations) (s 51(xx)) and external affairs (s 51(xxix)). These subject matters of legislative power are often called 'heads of power'.

5 See, in particular, the Agricultural and Veterinary Chemicals Code Act 1994 (Cth), to which the Agricultural and Veterinary Chemicals (Agvet) Code is a Schedule.
} 
When the Commonwealth is the host jurisdiction, it does not necessarily rely on the Territories power. In fact, it is Commonwealth policy to treat the selfgoverning Territories essentially as if they were States. So, the Commonwealth might rely on its power to legislate with respect to constitutional corporations and interstate and overseas trade and commerce, and then seek the agreement of the States and Territories to apply the Commonwealth law in the 'gap' left by the law; that is, to non-constitutional corporations (such as natural persons and unincorporated associations) engaged in intrastate (or intraterritory) trade and commerce. This is essentially the approach used in relation to the regulation of therapeutic goods and poisons. ${ }^{6}$ It is also the approach used in the context of one of the most significant applied law schemes - the Australian Consumer Law — which substantially superseded the Trade Practices Act 1975 (Cth) and the State and Territory fair trading Acts in $2010 .^{7}$

Another, more recent, example involves the Marine Safety (Domestic Commercial Vessel) National Law Act 2012 (Cth), which is part of a package of Acts enacted by the Commonwealth in 2012 to ensure the registration and safe operation of all commercial vessels. The Commonwealth Act applies essentially to vessels engaged in interstate trade and commerce, vessels owned by constitutional corporations, vessels covered by the implementation of international agreements, vessels that are external to Australia and vessels owned by the Commonwealth. It is proposed that the States and the NT will apply the National Law in the relatively small 'gap' left by the Commonwealth Act (essentially, in the waters within the limits of the States or the NT).

As already mentioned, the Commonwealth is not always the host jurisdiction. Sometimes it is simply a participating jurisdiction, as in the case of the three applied law schemes regulating the energy sector. Each of these applied law schemes features South Australia (SA) as the host jurisdiction. ${ }^{8}$

In other cases, the Commonwealth enacts no legislation at all. A number of recent applied law schemes involve one State as host jurisdiction and each other State and the Territories applying the law of the host jurisdiction in their jurisdictions. In this case, the 'gap' which is being 'filled' by the laws of the participating jurisdictions is not a result of the fact that the host jurisdiction is empowered to legislate only with respect to particular subject matters. After all, unlike the Commonwealth, the States (and the Territories) are able to legislate

6 See, in particular, the Therapeutic Goods Act 1989 (Cth).

7 See, in particular, the Competition and Consumer Act 2010 (Cth), to which the Australian Consumer Law is a Schedule.

8 See, in particular, the National Electricity (South Australia) Act 1996 (SA), to which the National Electricity Law is a Schedule; the National Gas (South Australia) Act 2008 (SA), to which the National Gas Law is a Schedule; and the National Energy Retail Law (South Australia) Act 2011 (SA), to which the National Energy Retail Law is a Schedule. 
with respect to essentially any subject matter. ${ }^{9}$ Rather, the 'gap' is a result of the fact that the host jurisdiction's power to legislate extraterritorially (that is, with respect to persons, acts, omissions, events, matters, things, etc outside the host jurisdiction) is limited. ${ }^{10}$ The applied law schemes for the regulation of early childhood education and care, ${ }^{11}$ health practitioners, ${ }^{12}$ occupational licensing, ${ }^{13}$ railway safety, ${ }^{14}$ co-operatives ${ }^{15}$ and heavy vehicles ${ }^{16}$ are purely State- and Territory-based applied law schemes. The still-stalled applied law scheme for the regulation of the legal profession is also in this category.

\section{Applied law schemes and responsible government: Some issues}

\section{Introduction: The concept of responsible government}

With the above overview of applied law schemes in mind, it is necessary now to return to the core question: do applied law schemes undermine responsible government? This is obviously a rather large question. So, the ensuing discussion seeks to address it by focusing on only four issues:

- First, 'application methods'; that is, the various ways in which a participating jurisdiction might apply a National Law in its jurisdiction.

9 A caveat to this is that s 52 of the Constitution gives the Commonwealth Parliament exclusive power with respect to a limited range of subjects. See also s 90 in relation to duties of custom and excise. Further, while the States may legislate with respect to a very wide variety of subject matters, State legislation which is inconsistent with Commonwealth legislation will, to the extent of the inconsistency, be invalid: see s 109. Territory legislation is also apt to be invalidated by Commonwealth legislation (in circumstances of 'repugnancy').

10 The States and Territories are able to enact laws with extraterritorial effect. However, there must be a 'sufficient connection' between the enacting State or Territory and the extraterritorial persons, acts, omissions, events, matters, things, etc in relation to which the State or Territory law operates. This requirement flows from the State Constitutions and the self-government Acts of the Territories, which relevantly mandate that State or Territory laws must be for the 'peace, order and good government' of the State or Territory concerned. See generally Pearce $v$ Florenca (1976) 135 CLR 507, 517-8; Union Steamship Co of Australia Pty Ltd $v$ King (1988) 166 CLR 1, 14; and Port MacDonnell Professional Fishermen's Association Inc v South Australia (1989) CLR 340, 372 .

11 Victoria is the host jurisdiction for this scheme. See, in particular, the Education and Care Services National Law Act 2010 (Vic), to which the Education and Care Services National Law is a Schedule.

12 Queensland is the host jurisdiction for this scheme. See, in particular, the Health Practitioner Regulation National Law Act 2009 (Qld), to which the Health Practitioner Regulation National Law is a Schedule.

13 Victoria is again the host jurisdiction for this scheme. See, in particular, the Occupational Licensing National Law Act 2010 (Vic), to which the Occupational Licensing National Law is a Schedule.

$14 \mathrm{SA}$ is the host jurisdiction for this scheme. See, in particular, the Rail Safety National Law (South Australia) Act 2012 (SA), to which the Rail Safety National Law is a Schedule.

15 New South Wales (NSW) is the host jurisdiction for this scheme. See, in particular, the Co-operatives (Adoption of National Law) Act 2012 (NSW), to which the Co-operatives National Law is a Schedule.

16 Queensland is again the host jurisdiction for this scheme. See, in particular, the Heavy Vehicle National Law Act 2012 (Qld), to which the Heavy Vehicle National Law is a Schedule. 
- Secondly, the interpretation of a National Law.

- Thirdly, the establishment of a so-called 'single national regulator' to administer and enforce a National Law.

- Finally, the treatment of a participating jurisdiction's suite of administrative laws upon the enactment of a National Law

Before turning to those issues, however, it is necessary to offer a working definition of 'responsible government'. The concept is, of course, a famously slippery one. However, in the recent case of Williams $v$ Commonwealth, Kiefel J distilled its essence neatly:

The relationship [responsible government] establishes between the Parliament and the Executive may be described as one where the former is superior to the latter. ${ }^{17}$

In other words, according to Kiefel J, responsible government is fundamentally about parliamentary supremacy.

Professor Cheryl Saunders has seconded Kiefel J's emphasis on parliamentary supremacy. However, she has also identified additional features. According to Saunders, responsible government assumes

that governments are responsible to parliaments and, through parliaments, to voters; [that] the parliament makes or authorises the making of rules that create or change law; that most of the information necessary for the voters to make their electoral judgment is in the public domain; and that courts review the legality of the exercise of public power within a system of somewhat delicate checks, balances and conventional practices. ${ }^{18}$

In Saunders' view, then, responsible government involves more than just parliamentary supremacy. It also involves members of the public knowing what they need to know and, when aggrieved by a decision, having reasonable access to avenues of review. ${ }^{19}$

17 (2012) 248 CLR 156, [579].

18 See C Saunders, 'Collaborative Federalism' (2002) 61 Australian Journal of Public Administration 69, 73. See also C Saunders, 'A New Direction for Intergovernmental Arrangements' (2001) 12 Public Law Review 274, 276, where Saunders writes: 'Stripped to its bare essentials, parliamentary responsible government is a system in which Parliaments are directly elected by voters and governments hold office with the support of a majority in the most popular House. Between elections, the Parliament holds the government and administration accountable. Its ability to do so is reinforced by the requirements of parliamentary approval for taxing and spending. New and altered laws require the approval of Parliament. Regularly, every three or four years, voters have the opportunity to change the government by changing the parliamentary majority. To this end, voters need the capacity to evaluate the government's record.'

19 Saunders speaks of judicial review, but arguably, in the context of the modern regulatory state, administrative (merits) review is also an aspect of responsible government. Other avenues of review such as the making of freedom of information (FOI) requests, the making of applications for review by the Ombudsman, and so forth — may also be thought to be included. 
With these definitions in mind, it is necessary now to turn to the first issue mentioned above: application methods.

\section{Application methods}

As discussed above, under an applied law scheme:

- the host jurisdiction enacts a National Law; and

- each participating jurisdiction enacts an application Act which applies the National Law.

It is important to understand, however, that this description disguises considerable complexity, because participating jurisdictions may 'apply' a National Law in one of a number of ways.

In what may be described as a 'true' applied law scheme, a participating jurisdiction applies the National Law as in force in the host jurisdiction from time to time. An example of this approach may be seen in the Health Practitioner Regulation National Law (Victoria) Act 2009 (Vic), which applies, as a law of Victoria, the Health Practitioner Regulation National Law enacted by Queensland. Section 4, which is the critical provision, provides as follows:

\section{Application of Health Practitioner Regulation National Law}

The Health Practitioner Regulation National Law, as in force from time to time, set out in the Schedule to the Health Practitioner Regulation National Law Act 2009 of Queensland

(a) applies as a law of Victoria; and

(b) as so applying may be referred to as the Health Practitioner Regulation National Law (Victoria); and

(c) so applies as if it were part of this Act.

When a participating jurisdiction applies a National Law as in force in the host jurisdiction from time to time, this means that, each time the host jurisdiction amends the National Law, the amendments apply automatically in the participating jurisdiction. There is no need for the Parliament of the participating jurisdiction itself to enact an amending Act. Nor is there any need for the amendments to be tabled or laid before the Parliament of the participating jurisdiction. In fact, parliamentarians in the participating jurisdiction may not even be aware that the National Law, as it applies in that jurisdiction, has changed. 
This feature of applied law schemes - which ensures the easy maintenance of regulatory uniformity - is probably their foremost advantage. It is also what really distinguishes them from mirror law schemes. In a mirror law scheme, participating jurisdictions might agree to amend their legislation simultaneously. But often they do not. Governments change. The priority accorded to the particular amendments varies from jurisdiction to jurisdiction. And, before you know it, the legislation in, say, Queensland may be quite different to the legislation in SA. ${ }^{20}$ However, this feature is also a controversial one, largely because it is seen as having the potential both to erode each participating jurisdiction's 'independence' or 'autonomy' (its 'sovereignty', if you will), and to undermine the role, and more importantly the supremacy, of its Parliament. As a result of these concerns, some jurisdictions have adopted alternative methods of applying a National Law.

The first alternative method is as follows:

- the participating jurisdiction enacts an application Act which applies a National Law as in force in the host jurisdiction from time to time; but

- the participating jurisdiction also includes in its application Act a provision requiring any amendments made to the National Law by the host jurisdiction to be tabled in the Parliament of the participating jurisdiction.

An example of this method may be seen in the Education and Care Services National Law (Application) Act 2011 (Tas), which applies, as a law of Tasmania, the Education and Care Services National Law as in force in Victoria from time to time, but which also provides:

\section{Tabling of amendments to Education and Care Services National Law (Tasmania)}

(1) The Minister is to cause any amendment to the Education and Care Services National Law (Tasmania) to be tabled in each House of Parliament within 10 sitting-days from the date on which the amendment receives the Royal Assent in Victoria.

(2) Nothing in this section affects the operation of that amendment.

It is important to note, however, that while amendments to the National Law must be tabled in the Parliament, the Parliament is given no express power to amend the amendments, or to 'disapply' them altogether. (The process may thus be contrasted to the process, familiar in most jurisdictions, by which subordinate legislation is laid before the Parliament and may be disallowed by

20 See generally Justice R S French, 'Cooperative Federalism: A Constitutional Reality or a Political Slogan' (paper presented at the 'Western Australia 2029: A Shared Journey' conference, Perth, 2004) 15. 
either House..$^{21}$ ) As a result, the amendments still come into effect automatically. However, this strategy does ensure that parliamentarians in the participating jurisdiction are aware of the ongoing evolution of the National Law as applied in that jurisdiction.

The second alternative method is similar to the first, in that the participating jurisdiction enacts an application Act which applies the National Law as in force in the host jurisdiction from time to time. However, the application Act then provides that any amendments made to the National Law by the host jurisdiction may be disapplied or proclaimed to have no effect. An example of this method may be seen in the Fair Trading Act 1987 (NSW), which applies, as a law of NSW, the Australian Consumer Law as in force in the Commonwealth from time to time, but which also provides:

\section{Future modifications of Australian Consumer Law text}

(1) A modification made by a Commonwealth law to the Australian Consumer Law text after the commencement of this section does not apply under section 28 [which is the section that applies the Australian Consumer Law in NSW] if the modification is declared by a proclamation to be excluded from the operation of that section.

It is worth noting, however, that this method invariably involves disapplication by the executive - usually by the Governor acting on the advice of the Minister or the Executive Council - rather than by the Parliament. So, while this method might go some way to ensuring the maintenance of a participating jurisdiction's sovereignty, it does not necessarily answer the concern of those worried about the relative power of the executive vis-à-vis the Parliament.

The third alternative method is quite different from the first two. It involves a participating jurisdiction enacting an application Act that applies the National Law as in force in the host jurisdiction at a particular time - usually the time that the participating jurisdiction's application Act commences — rather than from time to time. ${ }^{22}$ This means, of course, that when the host jurisdiction amends the National Law, the amendments do not apply automatically in the participating jurisdiction. However, to ensure that regulatory uniformity is easily maintained, the application Act of the participating jurisdiction goes

\footnotetext{
21 See, for example, the Legislative Instruments Act 2003 (Cth) pt 5.

22 In circumstances where a participating jurisdiction applies the National Law as in force in the host jurisdiction at a particular time, one may question whether the participating jurisdiction has 'applied' the National Law in any real sense. Arguably, what it has done is enact an Act which mirrors the National Law. As between the host jurisdiction and the participating jurisdiction, the resulting scheme is then best thought of as a mirror law scheme, rather than an applied law scheme. On this issue, the views of Roger Jacobs, a drafter at the Parliamentary Counsel's Office of Western Australia, would seem to be correct. See R Jacobs, 'National Applied Laws Schemes: A WA Perspective' (paper presented at the Australasian Drafting Conference, Adelaide, 2011) 26.
} 
on to provide that, when the host jurisdiction amends the National Law, the executive of the participating jurisdiction may make regulations which amend the National Law as it applies in the participating jurisdiction. In other words, the application Act provides for 'executive amendment' or 'updating' of the National Law. Provisions of this sort are rather evocatively called 'Henry VIII clauses'. An example of such a clause may be seen in the Occupational Licensing National Law (South Australia) Act 2011 (SA), which applies, as a law of SA, the Occupational Licensing National Law as in force in Victoria at a particular time, but which also provides:

\section{Amendments to Schedule to maintain national consistency}

(1) If -

(a) the Parliament of Victoria enacts an amendment to the Occupational Licensing National Law set out in the Schedule to the Occupational Licensing National Law Act 2010 of Victoria; and

(b) the Governor is satisfied that an amendment that corresponds, or substantially corresponds, to the amendment made by the Parliament of Victoria should be made to the Occupational Licensing National Law (South Australia), the Governor may, by regulation, amend the South Australian Occupational Licensing National Law text.

This method, like the second method, preserves jurisdictional sovereignty better than it does parliamentary supremacy.

The fourth alternative method is like the third, in that it involves a participating jurisdiction enacting an application Act that applies the National Law as in force in the host jurisdiction at a particular time, rather than from time to time. However, it differs in that the application Act does not provide for 'executive amendment' or 'updating' of the National Law. Consequently, when the host jurisdiction amends the National Law, the only way that the participating jurisdiction can 'keep up' is if its Parliament amends the National Law as it applies in the participating jurisdiction.

The fifth and final alternative method is the least like a 'true' application of a National Law. It involves a participating jurisdiction enacting an application Act that applies the National Law - either from time to time or at a particular time, although more typically the latter — and then modifies that National Law in some way in and for the participating jurisdiction. When a participating jurisdiction adopts this method, the resulting applied law scheme is necessarily non-uniform as between the host jurisdiction and the participating jurisdiction. An example of this strategy may be seen in the Health Practitioner Regulation (Adoption of National Law) Act 2009 (NSW), which applies, as a law of NSW, 
the Health Practitioner Regulation National Law as in force in Queensland from time to time, but which also modifies that National Law. Section 4 of the NSW Act, which is the critical provision, provides as follows:

\section{Adoption of Health Practitioner Regulation National Law}

The Health Practitioner Regulation National Law, as in force from time to time, set out in the Schedule to the Health Practitioner Regulation National Law Act 2009 of Queensland:

(a) applies as a law of this jurisdiction, with the modifications set out in Schedule 1, and

(b) as so applying may be referred to as the Health Practitioner Regulation National Law (NSW), and

(c) so applies as if it were a part of this Act.

Schedule 1 then disapplies the provisions of the National Law which relate to the health, performance and conduct of health practitioners, and creates a NSW-specific regime to deal with those matters.

The fact that there are a range of ways in which participating jurisdictions may 'apply' a National Law — with different strategies favoured by different jurisdictions - means that applied law schemes will often be extremely complicated. This complexity, by itself, might be thought to raise responsible government concerns. After all, as discussed above, the concept of responsible government connotes both the ready availability of information (for the purpose of assisting members of the public to make their electoral judgment, among other purposes) and the ready accessibility of avenues of review. Arguably, the greater the complexity of the law, the less likely it is that members of the public will be able either to understand the information relevant to their judgment or (without significant time and cost) to access their review rights. ${ }^{23}$

Ultimately, however, what is clear from the above discussion of application methods is that there is a tension at the heart of any applied law scheme. The legal mechanisms necessary to ensure the attainment, and maintenance, of regulatory uniformity may be seen as undermining jurisdictional sovereignty and Parliamentary supremacy; while the mechanisms necessary to maintain jurisdictional sovereignty and Parliamentary supremacy will invariably undermine the goal of regulatory uniformity.

23 It is worth noting here that the complexity of the Corporations Law scheme attracted considerable negative comment in Hughes. See, for example, 551, 573. 


\section{Interpretation of an applied law scheme}

Imagine a situation — one which, it must be said, rarely occurs in practice where all participating jurisdictions apply the National Law as in force in the host jurisdiction from time to time, and without making any jurisdiction-specific modifications. Imagine also that a single national regulator is created to oversee the National Law, thus ensuring uniform administration and enforcement. (The creation of a regulator is addressed in further detail below.) Even in such a situation, ongoing regulatory uniformity could not be guaranteed. This is because the National Law as applied in each participating jurisdiction would be interpreted - by lawyers, the regulator and the courts - by reference to different interpretation Acts. The Interpretation Act 1987 (NSW) in NSW, the Interpretation of Legislation Act 1984 (Vic) in Victoria, the Legislation Act 2001 (ACT) in the ACT, and so forth. Over time, subtle - but potentially significant - differences could emerge, even if the text of the National Law remained identical nationwide.

Government lawyers and drafters have been alive to this potential problem since the days of the first applied law schemes, and have sought to combat it in two main ways:

Approach 1: each participating jurisdiction disapplies its interpretation Act (insofar as the National Law is concerned) and the National Law itself includes rules for the Law's interpretation. This approach has been adopted in the context of the applied law schemes regulating electricity, gas, energy retail, early childhood education and care, health practitioners, occupational licensing, railway safety and co-operatives, among others.

Approach 2: each participating jurisdiction disapplies its interpretation Act (insofar as the National Law is concerned) and instead applies the interpretation Act of another jurisdiction. This approach has been adopted in the context of the Australian Consumer Law and the Agvet scheme.

Do either of these approaches raise any responsible government concerns? Arguably not. After all, each approach involves only the disapplication of a 'mere' interpretation Act, and that interpretation Act is being disapplied only insofar as one piece of legislation (the National Law) is concerned. However, if one considers the purpose interpretation Acts are intended to serve, the answer might be different. An interpretation Act is supposed to be the place - the one place, the common law aside - where the people living in a particular jurisdiction may look to make sense of the rest of the laws that govern them. That is, an interpretation Act plays a critical role in the 'knowability' and 'accessibility' of the law. Seen in this light, the problem with its disapplication reveals itself. The more applied law schemes a particular jurisdiction participates 
in, the more times its interpretation Act is disapplied. Over time, a jurisdiction's interpretation Act might go from being an important means of promoting community understanding of the law to a key that fits only every third or fourth lock.

Besides, even for those disinclined to think that the disapplication of an interpretation Act raises any real responsible government concerns, it is worth noting that two jurisdictions - Victoria and the ACT — have not just a 'standard' interpretation Act, but also an Act which requires the jurisdiction's legislation to be interpreted compatibly with human rights. ${ }^{24}$ These Acts obviously reflect a very significant policy choice made by the jurisdictions which have adopted them. They are not Acts to be disapplied lightly.

It is true that, at least to date, neither Victoria nor the ACT has expressly disapplied its human rights Act. But there is a serious question whether each jurisdiction's human rights Act has any scope to operate in the context of an applied law scheme. ${ }^{25}$ After all, each jurisdiction's human rights Act requires legislation to be interpreted in a way that is compatible with human rights 'so far as it is possible to do so consistently with its purpose' ${ }^{26}$ What is the purpose of a National Law as it applies in either Victoria or the ACT? Well, clearly a purpose - if not the primary purpose — of a National Law is to achieve a uniform nationwide scheme. So will the Victorian and ACT courts consider it 'possible' to interpret a National Law as it applies in either jurisdiction compatibly with human rights, even if such an interpretation might undermine the goal of nationwide regulatory uniformity? Or will they think it impossible? And, if the latter, could it not be said that the very significant decisions made by the legislatures of Victoria and the ACT - in enacting Acts designed to accord substantial priority to human rights issues - have been quietly undermined?

The courts do not appear to have wrestled with the issue so far. But this may simply reflect the fact that many of the existing applied law schemes entail regulation which is basically 'economic' in nature; human rights issues are thus less apt to arise. As the applied law schemes penetrate into other areas early childhood education and care, for example, or the regulation of health practitioners - this situation may well change. It is, if nothing else, an issue to watch.

24 See the Charter of Human Rights and Responsibilities Act 2006 (Vic) ('Victorian Human Rights Charter') and the Human Rights Act 2004 (ACT) ('ACT Human Rights Act').

25 See, on this question, Parliamentary Counsel's Committee, Protocol on Drafting National Uniform Legislation (2008) 10. See more broadly cases such as Australian Securities Commission v Marlborough Gold Mines Ltd (1993) 177 CLR 485, 492, where the High Court stressed the importance of 'uniformity of decision in the interpretation of uniform national legislation'.

26 See the Victorian Human Rights Charter s 32 and the ACT Human Rights Act s 30. 


\section{Creating a single national regulator to administer and enforce an applied law scheme}

Attaining and maintaining uniformity in the text of a National Law, as applied in participating jurisdictions, is obviously critical to ensuring the existence of a truly nationwide regulatory scheme. However, it is only one part of the equation. Uniformity in administration and enforcement is also vital. ${ }^{27}$ After all, a person's 'experience' of the law is likely to be shaped as much, if not more, by how that law is translated into practice by regulators as it is by the words on the face of the statute book. ${ }^{28}$ It is for this reason that it is generally seen as desirable for there to be a single national regulator for all participating jurisdictions, rather than a separate jurisdiction-specific regulator for each participating jurisdiction.

The creation of a single national regulator is legally complicated. However, generally speaking, there are two main approaches.

- Approach 1: the provisions establishing the regulator are not set out in the National Law, but in a separate Act of one of the participating jurisdictions (usually, but not invariably, the host jurisdiction). They are thus not applied by all participating jurisdictions. By contrast, the provisions conferring the regulator's functions and powers are set out in the National Law, and are thus applied by all participating jurisdictions.

- Approach 2: both the provisions establishing the regulator and the provisions conferring its functions and powers are set out in the National Law itself, and are thus applied by all participating jurisdictions.

The first approach is the 'traditional' approach — in the sense that it was used in many of the earlier applied law schemes, including the Corporations Law scheme - and remains the approach used in all of the applied law schemes in which the Commonwealth is a participating jurisdiction. The second approach has become the more common approach in recent years, and is the approach used in essentially all of the purely State and Territory-based applied law schemes. As will be discussed below, it is also the approach which arguably raises the more serious responsible government concerns.

The first approach was subject to detailed consideration in Hughes. As noted above, Hughes concerned the Corporations Law scheme, which involved a regulator established under a Commonwealth law purporting to perform

\footnotetext{
27 C Saunders, 'A New Direction for Intergovernmental Arrangements' (2001) 12 Public Law Review 276.

28 The issue of the interpretation, administration and enforcement of the law by regulators has received comparatively greater attention in the United States than in Australia. See, for example, R D Moss, 'Executive Branch Legal Interpretation' (2000) 52 Administrative Law Review 1303, 1304, where Moss observes that 'the executive branch is perpetually involved in giving the law meaning ... In the vast majority of cases, moreover, executive branch interpretation is not subjected to judicial review.'
} 
functions under State laws (namely, the State laws which applied the National Law that the Commonwealth had enacted for the ACT). Put simply, the question for the High Court was whether the Commonwealth regulator was able to perform the functions conferred under the State laws. The resulting decision is complex, or, to borrow the words of Saunders again, 'somewhat unclear'. ${ }^{29}$ However, the case appears to stand for a number of propositions: ${ }^{30}$

- First, while a State may confer a function on a Commonwealth regulator, a Commonwealth law must 'authorise' or 'permit' that conferral; that is, it must authorise or permit the Commonwealth regulator to perform the State function. This is necessary to ensure that there is no inconsistency for the purposes of s 109 of the Constitution between the State conferral and any Commonwealth legislation (in particular, the Commonwealth legislation establishing the relevant regulator). It may also be necessary to 'waive' any constitutional immunity that Commonwealth bodies or officers have from State laws that purport to apply to them.

- Secondly, and more significantly, it is necessary to consider whether the Commonwealth regulator is under a duty to perform the State function: ${ }^{31}$

- If there is not a duty: it seems that the Commonwealth regulator may perform the State function, whether or not there is a connection between this function and a head of Commonwealth legislative power.

- If there is a duty: the Commonwealth law authorising or permitting the Commonwealth regulator to perform the State function will only be valid if there is a connection between the State function and a head of Commonwealth legislative power. (This is likely to be especially so in circumstances where the performance of the function is 'coercive' in some way; that is, capable of affecting the rights of individuals.)

Both of these propositions are capable of presenting problems in practice. The first proposition, for instance, makes it necessary to consider when, as a matter of statutory construction, the Commonwealth has authorised or permitted the conferral of State functions on a Commonwealth regulator. An interesting

29 C Saunders, 'A New Direction for Intergovernmental Arrangements' (2001) 12 Public Law Review 274.

30 See, in particular, the helpful analysis in G Hill, ' $R v$ Hughes and the Future of Cooperative Legislative Schemes' (2000) 24 Melbourne University Law Review 478, 490-1, upon which this chapter relies. See also D Rose and G Lindell, 'A Constitutional Perspective on Hughes and the Referral of Powers' (paper presented at the Corporate Law Teachers Association Conference, 3 November 2000); D Rose, 'The Hughes Case: The Reasoning, Uncertainties and Solutions' (2000) 29 University of Western Australia Law Review 180; I Govey and H Manson, 'Measures to Address Wakim and Hughes: How the Reference of Powers Will Work' (2001) 12 Public Law Review 1; M J Whincop, 'The National Scheme for Corporations and the Referral of Powers: A Sceptical View' (2001) 12 Public Law Review 263; B M Selway, 'Hughes Case and the Referral of Powers' (2001) 12 Public Law Review 288; G Hill, 'Revisiting Wakim and Hughes: The Distinct Demands of Federalism' (2002) 13 Public Law Review 205; D Rose, 'Commonwealth-State Cooperative Schemes After Hughes: What Should be Done Now?' (2002) 76 Australian Law Journal 631; G Williams, 'Cooperative Federalism and the Revival of the Corporations Law: Wakim and Beyond' (2002) 20 Company and Securities Law Journal.

31 There is some suggestion that this might be a 'constitutional imperative'. See Hughes 553-4. 
example of this involves s 44AI of the Competition and Consumer Act 2010 (Cth), which authorises or permits the Australian Energy Regulator (AER), which has important responsibilities under the three applied law schemes regulating the energy sector, to perform certain State functions. Section 44AI relevantly provides:

44AI Commonwealth consent to conferral of functions etc on AER

(1) A State/Territory energy law may confer functions or powers, or impose duties, on the AER for the purposes of that law.

(3) The AER cannot perform a duty or function, or exercise a power, under a State/Territory energy law unless the conferral of the function or power, or the imposition of the duty, is in accordance with the Australian Energy Market Agreement, or any other relevant agreement between the Commonwealth and the State or Territory concerned.

As a result of s $44 \mathrm{AI}(3)$, the question whether the AER is relevantly authorised or permitted to perform a State function shifts from being a question of interpreting the relevant Commonwealth Act to a question of construing the relevant State Act: does it 'confer functions or powers, or impose duties, on the AER'? It then shifts again to become a question of interpreting the Australian Energy Market Agreement (AEMA) ${ }^{32}$ or any other relevant intergovernmental agreement. The latter task is not always easy. In large part, this is because the AEMA, and the other relevant intergovernmental agreements, are not drafted with the precision of legislation or of ordinary contracts. Indeed, they could even be said to exhibit a certain 'wooliness' of language. ${ }^{33}$ The upshot is that, in individual cases, it can be a complex and time-consuming process to determine whether a State conferral is 'in accordance with' the AEMA or any other relevant intergovernmental agreement, and thus, whether the Commonwealth has authorised or permitted the AER to perform the relevant State function.

The second proposition enunciated by the High Court in Hughes — namely, that where a Commonwealth regulator is under a duty to perform a State function, the Commonwealth law authorising or permitting this will be valid only if

32 The AEMA is the intergovernmental agreement which underpins the three applied law schemes regulating the energy sector.

33 The lack of precision evident in many intergovernmental agreements reflects the fact that, generally speaking, they are not intended to create, and do not create, binding legal relations. See N Seddon, Government Contracts: Federal, State and Local (Federation Press, 5th ed, 2013) 118-20. See further South Australia v Commonwealth (1961) 108 CLR 130, 154. 
there is a connection between the State function and a head of Commonwealth legislative power - is also problematic. As Associate Professor Andrew Lynch and Professor George Williams explain:

In requiring a legislative source of power to support the Commonwealth's imposition upon its [regulators] of 'powers coupled with duties ...', Hughes substantially curtailed the usefulness of cooperation in many instances. If the Commonwealth must have the legislative authority to support those powers conferred by the States operating as [duties] upon its [regulators], and a suitable power can be found, then, ironically, the Commonwealth may already have the means to legislate to this end without any need for State cooperation. If, conversely, no Commonwealth power can be sourced, then no agreement with the States can make good the deficiency. ${ }^{34}$

The Commonwealth has responded to Hughes by inserting into relevant Commonwealth legislation ${ }^{35}$ clauses (Hughes clauses) which do a number of things:

- First, they explain when a State law will purport to impose a duty on a Commonwealth regulator.

- Secondly, they provide that, if a State purports to impose a duty on the Commonwealth regulator, the duty is taken to be imposed under State law to the extent to which this is within the legislative power of the State and consistent with relevant constitutional doctrines.

- Thirdly, they provide that, if the duty is not taken to be imposed on the Commonwealth regulator under State law (because of an absence of State legislative power or the operation of relevant constitutional doctrines), the duty is instead taken to be imposed by Commonwealth law (to the extent to which this is within the legislative power of the Commonwealth and consistent with relevant constitutional doctrines). ${ }^{36}$

- Fourthly, they provide that, if the imposition of the duty on the Commonwealth regulator exceeds both State and Commonwealth legislative

34 See A Lynch and G Williams, 'Beyond a Federal Structure: Is a Constitutional Commitment to a Federal Relationship Possible?' (2008) 31 University of New South Wales Law Journal 395, 419.

35 See, for one example, the Therapeutic Goods Act 1989 (Cth) ss 6AAA-6AAC.

36 Hughes clauses ordinarily provide that if the relevant duty is taken to be imposed by Commonwealth law, then it is the intention of the Parliament 'to rely on all powers available to it under the Constitution to support the imposition of the duty'. One question that arises in this context is: will a court go looking for possible heads of power, or do they need to be spelled out in the legislation? See, on this point, M Farnan, 'Commonwealth-State Cooperative Schemes: Issues for Drafters' (paper presented at the Australasian Drafting Conference, Sydney, 2005) 15. The conventional view is that, notwithstanding s 15A of the Acts Interpretation Act 1901 (Cth) ('AI Act'), the courts will not go looking for possible heads of power. See generally The King $v$ Poole; Ex parte Henry (No 2) (1939) 61 CLR 634, 652; Pidoto v Victoria (1943) 68 CLR 87, 108-10; Bank of NSW v Commonwealth (1948) 76 CLR 1, 371; Strickland v Rocla Concrete Pipes Ltd (1971) 124 CLR 468, 493; Re Dingjan; Ex parte Wagner (1995) 183 CLR 323, 339; Victoria v Commonwealth (1996) 187 CLR 416, 501-3. 
power or contravenes relevant constitutional doctrines, the regulator is taken to have a discretionary power (to perform the relevant function), rather than a duty.

Hughes clauses are designed to preserve the constitutional validity of applied law schemes, and to ensure that Commonwealth regulators are at least empowered (if not obliged) to administer and enforce them. However, they have not yet been tested in the High Court. The question whether the Court would regard them as fully coming to terms with the requirements identified in Hughes thus remains open.

Hughes issues arise only where the single national regulator is a Commonwealth officer or body. However, even where administration occurs at the State and Territory level, it is possible that constitutional issues may still arise. There is a doctrine of constitutional law - known as the Melbourne Corporation doctrine - which prohibits the Commonwealth from enacting laws which, in their 'substance and operation', constitute 'in a significant manner a curtailment or interference with the exercise of State constitutional power' ${ }^{37}$ Relevantly, the effect of the doctrine would appear to be as follows:

- The Commonwealth may confer discretionary functions and powers on a State regulator - that is, it may authorise a State regulator to do something - irrespective of whether or not the relevant State consents (assuming, of course, that the Commonwealth possesses the power to legislate in the first place).

- However, the Commonwealth may not impose obligations or duties on a State regulator - that is, it may not require a State regulator to do something in the absence of the relevant State's consent.

The issue of what would constitute State 'consent' for the purposes of the Melbourne Corporation doctrine is the subject of some uncertainty. Clearly, a State could consent by enacting appropriate legislation. One would ordinarily expect this to occur in the context of an applied law scheme (although careful attention would need to be paid to drafting issues). Alternatively, it is possible that a Commonwealth-State executive agreement (that is, an intergovernmental agreement) would suffice. Chief Justice Gleeson explored this issue in O'Donoghue $v$ Ireland. ${ }^{38}$ His Honour considered that, provided there is no State legislative impediment to the conferral of the obligation on the relevant State regulator (that is, no State legislation which operates, expressly or impliedly, so that the State regulator cannot perform the relevant function), there is no apparent reason why an executive agreement between the Commonwealth and the State should

37 See Austin v Commonwealth (2003) 215 CLR 185, 245-6. More generally, see Melbourne v Commonwealth (1947) 74 CLR 31 (the 'Melbourne Corporation case').

38 (2008) 234 CLR 599 ('O'Donoghue'). 
not be a sufficient manifestation of the State's consent. The High Court has not considered the issue again since O'Donoghue. It is unclear, therefore, whether a majority of the Court would be prepared to adopt Gleeson CJ's approach.

It is perhaps because of the complexities discussed above that attention has turned to alternative approaches to establishing, and conferring functions and powers on, the regulators of applied law schemes. However the second approach mentioned above - under which both the provisions establishing the regulator and the provisions conferring its functions and powers are set out in the National Law itself, and are thus applied by all participating jurisdictions - raises issues of its own (and arguably does nothing to address the issues raised in Hughes).

When the second approach is used, the National Law will include a provision along the following lines: ${ }^{39}$

\section{National Regulator}

(1) The National Regulator is established.

(2) The National Regulator-

(a) is a body corporate with perpetual succession; and

(b) has a common seal; and

(c) may sue and be sued in its corporate name.

(3) The National Regulator represents the [jurisdiction/State/Territory].

Based on a plain reading of this provision, it would appear that, each time it is applied by a participating jurisdiction - that is, each time a participating jurisdiction enacts an application Act which applies the National Law - a separate body corporate (having the features described in sub-ss (2) and (3)) is created in and for that participating jurisdiction.

However, the National Law will also contain a separate provision as follows: ${ }^{40}$

\section{Single national entity}

(1) It is the intention of the Parliament of this jurisdiction that the National Law as applied by an Act of this jurisdiction, together with the National Law as applied by Acts of other participating jurisdictions,

39 See, for example, the Health Practitioner Regulation National Law s 23; the Education and Care Services National Law s 224; the Occupational Licensing National Law s 97; the Rail Safety National Law s 12; and the Heavy Vehicle National Law, ss 597-8.

40 See, for example, the Health Practitioner Regulation National Law s 7; the Education and Care Services National Law s 7; the Occupational Licensing National Law s 6; the Rail Safety National Law s 9; and the Heavy Vehicle National Law s 597. 
has the effect that an entity established by the National Law is one single national entity, with functions conferred by this Law as so applied [emphasis added].

It is not easy to read the first provision together with the second. One possibility (seemingly the more legally defensible one) is that, whatever the intention of the Parliaments of the participating jurisdictions, the provisions of the National Law are simply not effective to create a 'single national entity'. So, while the National Regulator might, as a practical matter, operate as a 'single national entity', there is, as a legal matter, a separate body corporate, bearing the name of the National Regulator, in each participating jurisdiction. The other possibility, of course, is that the provisions of the National Law succeed in creating a 'single national entity', which is clearly their intention. ${ }^{41}$

However, leaving this issue aside, the real question for present purposes is this: to which executive, and thus which Parliament, is a regulator established under the second approach accountable? To the executive, and thus the Parliament, of the host jurisdiction? To the executive, and thus the Parliament, of the participating jurisdiction in which the regulator is based (if that is not the host jurisdiction)? To the executives, and the Parliaments, of all of the participating jurisdictions (perhaps via the Ministerial Council which, in the context of many applied law schemes, has overall responsibility for the scheme)? And if the latter, is there a risk that the regulator, by being accountable to everyone, might be accountable to no one? What if the regulator makes a controversial decision? What if it makes a mistake? Which Minister is going to answer for it, and in which Parliament?

\footnotetext{
41 There is High Court authority for the proposition that one jurisdiction may, jointly with another jurisdiction, establish a single body which derives its existence, functions and powers from the legislation of both jurisdictions. See, in particular, $R v$ Duncan; Ex parte Australian Iron and Steel Proprietary Ltd (1983) 158 CLR 535 ('Duncan') and Re Cram; Ex parte NSW Colliery Proprietors' Association Ltd (1987) 163 CLR 117 ('Cram'). In these cases - which concerned an attempt by the Commonwealth to create a body jointly with NSW - the Court placed great emphasis on how it thought the Commonwealth and NSW intended the relevant cooperative legislative scheme to operate. (It is, needless to say, a basic principle of statutory construction that, in interpreting the provisions of an Act, the interpretation that would best achieve the purpose or object of the Act is to be preferred over each other interpretation. See, for example, the AI Act s 15A.) However, even if the current Court were to regard the provisions of the National Laws in question as equivalent to the provisions at issue in Duncan and Cram (which is doubtful), it is by no means clear that it would be anywhere near as sympathetic as the Duncan and Cram courts were to appeals to the 'intention of Parliament' (or, more broadly, to appeals to the value of 'cooperation'). And even if it were prepared to be so, interesting questions would remain. For instance: would the 'single national entity' itself be a body corporate? That is, would the individual corporations established in the participating jurisdictions somehow become, by the force of parliamentary intention, a single corporation? Or would the 'single national entity' be some other kind of legal entity, its roots the individual corporations created by the participating jurisdictions? After all, as Deane J put it in Duncan: 'It is competent for the legislature to constitute ... an entity of a type unknown to the common law': at 587. But if this were found to have occurred, what would be the nature of this new legal entity? And would it have the powers of the individual corporations which begat it, like the power to contract or to acquire real or personal property?
} 
These and other questions might tend to suggest that the first approach mentioned above is the better one. Because this approach is careful to avoid any ambiguity about which participating jurisdiction is responsible for establishing, and has in fact established, the regulator, political accountability is easier to locate. After all, on this approach, it is clear that the regulator will be accountable - ultimately - to the executive, and thus the Parliament, of the jurisdiction which established it. To quote Chief Justice Robert French again:

It is reasonably arguable that accountability is optimised under a cooperative scheme when one government and one Minister has to be responsible for its administration. ${ }^{42}$

Hughes (and other) issues notwithstanding, it would therefore seem desirable to pursue the first, traditional approach, rather than the second, presently ascendant approach. ${ }^{43}$

\section{Administrative law issues}

The interpretation Acts of participating jurisdictions are not the only laws which are capable of operating 'in relation to' a National Law as applied in each participating jurisdiction in such a way as to produce different outcomes in different participating jurisdictions. A range of other laws may also have this effect. ${ }^{44}$ Notable in this respect are what might be described broadly as 'administrative laws'.

It is necessary here to distinguish between:

- laws relating to merits and (in particular) judicial review; and

- laws relating to:

42 Chief Justice R S French, 'The Incredible Shrinking Federation: Voyage to a Singular State' in G Appleby, $\mathrm{N}$ Aroney and T John (eds), The Future of Australian Federalism: Comparative and Interdisciplinary Perspectives (Cambridge University Press, 2012) 63.

43 This is not to say, of course, that the first approach raises no responsible government concerns. For instance, in the context of an applied law scheme involving, say, a regulator established under SA law which performs functions and exercises powers under the laws of all other States and Territories, will the executive and the Parliament of SA - the institutions to which the regulator is ostensibly accountable be as 'interested' in a controversial decision made by the regulator in NSW or Victoria as they would be if the same decision were made in SA? Will a person affected by a decision in NSW or Victoria have the same capacity to complain, or seek redress, as a person affected by a decision in SA? Graeme Hill has suggested that the High Court's decision in Bond $v$ The Queen (2000) 201 CLR 213 - which was a precursor to Hughes and also concerned the Corporations Law scheme - 'exhibits some concern that lines of political accountability are still unclear' even on the first approach. See G Hill, ‘Reviewing Decisions by Commonwealth Bodies Made Under State or Territory Legislation' (2006) 17 Public Law Review 112, 130.

44 Some commentators have described these laws as 'adjectival' or 'ancillary' laws. See, for instance, C Saunders, 'A New Direction for Intergovernmental Arrangements' (2001) 276; C Saunders, 'Cooperative Arrangements in Comparative Perspective' in G Appleby, N Aroney and T John (eds), The Future of Australian Federalism: Comparative and Interdisciplinary Perspectives (Cambridge University Press, 2012) 419. 
- review by the Ombudsman;

- privacy;

- FOI;

- financial management and accountability (including the auditing of regulators);

- public records or archives; and

- public service, administration and management.

Turning first to merits and judicial review, ${ }^{45}$ most of the recent applied law schemes have followed a fairly standard approach ${ }^{46}$ under which:

- the National Law includes basic provisions about review (concerning, for example, which decisions are reviewable, the review process, etc); and

- each participating jurisdiction's application Act includes provisions prescribing which State tribunal or court is responsible for carrying out the review. ${ }^{47}$

This approach ensures the continuing ready accessibility of avenues of review (and thus raises no particular responsible government concerns). However, its disadvantages in terms of ongoing regulatory uniformity are manifest. Depending on the approach of each participating jurisdiction's tribunals and courts, it is possible that a person aggrieved by an administrative decision in, say, Queensland might achieve a distinctly different result to a person aggrieved by the same (or a similar) decision in Victoria. Moreover, distinctly different interpretations of the National Law might spring up in different participating jurisdictions (notwithstanding common interpretative rules). Needless to say, this approach is also not ideal from the perspective of a single national regulator, which must contend with an array of different tribunals and courts, with varying rules and procedures (most of which will remain untouched by the National Law), in respect of the same decisions. ${ }^{48}$ Nor does this approach help to build expertise within a particular tribunal or court.

45 For a useful analysis of this issue, see G Hill, 'Reviewing Decisions by Commonwealth Bodies Made Under State or Territory Legislation' (2006) 17 Public Law Review. See also C Saunders, 'Administrative Law and Relations Between Governments: Australia and Europe Compared' (2000) 28 Federal Law Review 263, 269-70.

46 The adoption of this standard approach may reflect a concern not to transgress relevant constitutional limitations, in particular, the entrenched supervisory jurisdictions of the High Court and State Supreme Courts. See generally Plaintiff S157/2002 v Commonwealth (2003) 211 CLR 476; and Kirk v Industrial Court of NSW (2010) 239 CLR 531.

47 Further review or appeal will then generally occur within the hierarchy of tribunals and courts existing in the participating jurisdiction concerned.

48 This is something that applied law schemes are supposed to avoid. See K Graham, 'The Commonwealth's Response to Re Wakim: The Jurisdiction of Courts Legislation Amendment Act 2000' (2000) 26 AIAL Forum 33, 34. See also D O'Brien, 'Administrative Review Under the Corporations Law and the Australian Securities Commission Law' (1991) 9 Company and Securities Law Journal 235. 
Some applied law schemes have sought to address these problems by providing for the establishment of a specialist merits review body to review all decisions made under the scheme, with judicial review by the courts of only one jurisdiction. For example, in the context of the three applied law schemes regulating the energy sector, the Australian Competition Tribunal, established by a Commonwealth Act, conducts merits review, ${ }^{49}$ while judicial review is carried out by the federal courts under the Administrative Decisions (Judicial Review) Act 1977 (Cth) ('ADJR Act'). ${ }^{50}$

In relation to the broader package of administrative laws, the position is more complicated and (arguably) more problematic from a responsible government perspective. The standard approach in this context is one of 'disapplication and replacement'. That is, each participating jurisdiction disapplies its administrative laws (insofar as the National Law is concerned) and replaces those laws by:

- applying mutually agreed replacement rules insofar as some matters are concerned (usually financial management and accountability, auditing and the like); and

- applying the administrative laws of another jurisdiction (with necessary modifications) insofar as other matters are concerned (usually review by the Ombudsman, privacy and FOI).

This disapplication and replacement approach raises a number of responsible government concerns. For one thing, there is a question whether the functions served by the disapplied laws (functions which include ensuring the ready availability of information and the ready accessibility of avenues of review) will be properly served by whatever replaces them (assuming something does). In other words, will the mutually-agreed replacement rules, or the administrative laws of the other jurisdiction, be the equal of what they have supplanted? Even if they are, it is undeniable that the disapplication and replacement of a participating jurisdiction's administrative laws adds significant complexity to the law. ${ }^{51}$ Even for a trained lawyer, it can be difficult to discern precisely

49 This procedure - merits review by the Australian Competition Tribunal with judicial review by the federal courts - is applicable only in relation to certain bodies with functions and powers under the relevant National Laws (in particular, the AER). Other bodies with functions and powers under the National Laws (such as the Australian Energy Market Commission and the Australian Energy Market Operator) are subject to the standard approach under which their decisions are reviewed by the (prescribed) tribunals and courts of each participating jurisdiction. As of August 2013, the Standing Council on Energy and Resources - which is the Ministerial Council overseeing the applied law schemes regulating the energy sector — was conducting a review of the so-called 'limited merits review' process established under the schemes. The current proposal envisions the continuation of (altered) merits review by the Australian Competition Tribunal and judicial review by the federal courts.

50 The ADJR Act sch 3 prescribes the State and Territory Acts that apply the National Electricity Law, the National Gas Law and the National Energy Retail Law as 'enactments' for the purposes of the ADJR Act. 51 This complexity is most evident in circumstances where one participating jurisdiction disapplies its administrative laws and applies those of another jurisdiction. For example, when the States and Territories disapply their administrative laws and apply those of the Commonwealth - which occurs frequently, even 
what options are available for, say, making an application for review by the Ombudsman or making an FOI request. The barriers to entry (both in terms of time and cost) are considerable.

\section{Other issues}

The issues discussed above are not an exhaustive list of the challenges that applied law schemes pose (or potentially pose) to responsible government. Some further issues (although by no means all of them) are discussed below.

First, there is the issue of regulations. We have long since become used to the fact that the Parliament delegates significant legislative power to the executive. As a result of this practice, much of the real detail of any particular scheme is determined by the executive, via regulations or other subordinate legislation, rather than by the Parliament, via primary legislation. However, the understanding behind this practice is that the Parliament will scrutinise any regulations promulgated by the executive, and may easily disallow them. This is not necessarily the case in the context of applied law schemes. Most National Laws, like most ordinary Acts, contain broad regulation-making powers, with authority to make the regulations generally bestowed on either the relevant Ministerial Council ${ }^{52}$ or one executive (with the unanimous consent or 'recommendation' of the others). ${ }^{53}$ The National Laws also usually provide for the tabling of any regulations in the Parliament of each participating jurisdiction. However, the relevant disallowance provision often reflects an approach that is best described as 'majority rules'. The following provision, taken from the Health Practitioner Regulation National Law, offers an illustration: ${ }^{54}$

in the context of purely State and Territory-based applied law schemes, because the Commonwealth's laws are seen as 'neutral ground' - the Commonwealth's laws, as applied, must be modified so that, whenever they refer to a Commonwealth officer or body (such as the Australian Information Commissioner or the Commonwealth Ombudsman), the references are taken to be references to a State or Territory officer (or officers) or body (or bodies). This is necessary because, as discussed above, the States and Territories cannot unilaterally (that is, without Commonwealth consent) confer a function or power on a Commonwealth officer or body. A purported conferral of this sort would be invalid by virtue of s 109 of the Constitution and/or the Commonwealth's implied intergovernmental immunity. This is generally not the only modification that is necessary. Accordingly, it is common for National Laws to have broad regulation-making provisions which permit the regulations to modify the applied Commonwealth laws or to provide that the applied Commonwealth laws apply as if specific provisions were omitted or specific amendments to the Commonwealth laws (by the Commonwealth Parliament) had not taken effect.

52 See, for example, the Health Practitioner Regulation National Law s 245; the Education and Care Services National Law s 301; and the Occupational Licensing National Law s 160.

53 See, for example, the Rail Safety National Law s 264; the Co-operatives National Law s 612; and the Heavy Vehicle National Law s 669 .

54 It is worth noting that, under the Health Practitioner Regulation National Law, Victoria is responsible for the preparation and printing of regulations made by the Ministerial Council, notwithstanding that Queensland is the host jurisdiction: see s 245 of the National Law. This is but one of the many oddities that one may expect to find when looking at an applied law scheme in any detail. 
246 Parliamentary scrutiny of national regulations

(1) A regulation made under this Law may be disallowed in a participating jurisdiction by a House of the Parliament of that jurisdiction -

(a) in the same way that a regulation made under an Act of that jurisdiction may be disallowed; and

(b) as if the regulation had been tabled in the House on the first sitting day after the regulation was published by the Victorian Government Printer.

(2) A regulation disallowed under subsection (1) does not cease to have effect in the participating jurisdiction, or any other participating jurisdiction, unless the regulation is disallowed in a majority of the participating jurisdictions.

The effect of a provision like this is clear: the Parliaments of, say, SA and Tasmania, could find themselves 'out-voted' by those of the bigger States. And while the 'minority' Parliaments could presumably take extraordinary measures to disallow the regulations - up to and including 'withdrawing' from the applied law scheme altogether - it is likely that they would find themselves under considerable political pressure not to buck the horse.

Another issue concerns those jurisdictions which enact an application Act that applies the National Law but also modifies that National Law in some way in and for the participating jurisdiction. It is relatively common for these jurisdictions not to provide a 'consolidated' version of the National Law as modified by the application Act (NSW is an honourable exception to this trend). This leaves readers of the National Law with the unenviable task of trying to piece together their own 'consolidation', the National Law in one hand, the application Act in the other. This is hardly acceptable if, as discussed above, one regards responsible government as being at least in part about the 'knowability' and 'accessibility' of the law. ${ }^{55}$

A final issue concerns those jurisdictions, currently Victoria and the ACT, which have a human rights Act. The impact of applied law schemes on the 'interpretative duty' imposed by human rights Acts has already been mentioned. But it is also worth recalling that another key feature of human rights Acts is that they require the preparation of statements which accompany a Bill when it is introduced

55 The failure to provide suitable consolidations may also be seen in circumstances where participating jurisdictions apply the administrative laws of another jurisdiction (with modifications). In these circumstances, readers of the administrative laws, as applied, must have a copy of the original administrative laws, the National Law (which will usually modify the applied administrative laws to some extent) and the National Regulations (which will usually modify the applied administrative laws to a greater extent). 
into the Parliament which attest to the Bill's compatibility with human rights. ${ }^{56}$ While Victoria and the ACT have prepared statements of compatibility when they have applied a National Law for the first time, the statements have not necessarily been prepared for subsequent amendments to the Law. This is because, in circumstances where Victoria and the ACT apply a National Law as in force in the host jurisdiction from time to time (as they generally do), any amendment to the Law made by the host jurisdiction will apply automatically in Victoria and the ACT. The obligation to prepare a statement of compatibility, which arises only when a Bill is introduced to the Parliament, simply does not apply in these circumstances. ${ }^{57}$ It is possible, then, that applied law schemes have the capacity to undermine quite seriously the intended effect of human rights Acts, detracting not only from the interpretative duty they impose, but also from their potential, via the statement of compatibility process, to get parliamentarians thinking about human rights. ${ }^{58}$

\section{Conclusion}

There are those who hope that policy makers will begin to interrogate more closely 'the value of national uniformity', and ultimately come to 'reflect on the advantages of diversity and innovation that federalism potentially offers Australia'.$^{59}$ Such people are likely to be waiting a long time. The consensus be it unthinking or otherwise - that there is a strong economic and 'equality' case for regulatory uniformity seems strong and, if anything, growing stronger.

\footnotetext{
56 See the Victorian Human Rights Charter s 28 and the ACT Human Rights Act s 37. These statements are generally called 'statements of compatibility'.

57 This issue has attracted criticism in Victoria: see the Scrutiny of Acts and Regulations Committee, Parliament of Victoria, Review of the Charter of Human Rights and Responsibilities Act 2006 (2011) 95-6. In its response to this review, the Victorian Government stated that it 'does not intend to require statements of compatibility ... for amendments to national uniform schemes that entail the application of laws of another jurisdiction in Victoria. The initial legislation that implements a national applied law uniform scheme in Victoria is accompanied by a statement of compatibility and is subject to scrutiny by the Victorian Parliament and [the Scrutiny of Acts and Regulations Committee]. At that time, Parliament agrees to the content of the initial legislation, including the process for making amendments and regulations.' See Government of Victoria, Review of the Charter of Human Rights and Responsibilities Act 2006: Victorian Government Response (2012) 13-4.

58 The other main way that human rights Acts aim to promote human rights is to impose on 'public authorities' a duty to act compatibly with, and give proper consideration to, human rights. See the Victorian Human Rights Charter s 38 and the ACT Human Rights Act s 40B. Applied law schemes arguably have the potential to disrupt this obligation as well. Whether or not this is so may depend not only on the definition of 'public authority' adopted in each human rights Act, but also on the issues discussed above in relation to the establishment of a single national regulator. For example, when the second approach discussed above is utilised - that is, the approach under which both the provisions establishing the regulator and the provisions conferring its functions and powers are set out in the National Law itself, and are thus applied by all participating jurisdictions - is a separate body corporate, bearing the name of the regulator, established in each participating jurisdiction?

59 C Saunders, 'Cooperative Arrangements in Comparative Perspective' in G Appleby, N Aroney and T John (eds), The Future of Australian Federalism: Comparative and Interdisciplinary Perspectives (Cambridge University Press, 2012) 414, 430.
} 
A more realistic hope is that attempts to achieve regulatory uniformity might occur in a way that is more in keeping with our underlying constitutional system. This does not necessarily mean that applied law schemes should be jettisoned in favour of 'tighter' (reference schemes) or 'looser' (mirror law schemes) cooperative legislative schemes. ${ }^{60}$ But it does mean that, if applied law schemes are to be implemented, greater attention should be paid to what the concept of responsible government requires and implies. When a jurisdiction decides to participate in an applied law scheme, the most careful attention should be given to the method which is to be utilised to apply the law of the host jurisdiction: what role does that method give to the Parliament visà-vis the executive? And if that method inverts the usual power relationship between the Parliament and the executive, has the necessity of that inversion been both properly considered and properly explained to the voting public? Secondly, the relationship between the legislation necessary to enter into an applied law scheme and the balance of a jurisdiction's law - everything from its interpretation Act to its FOI Act to its public records or archives Act - must be considered. In particular, it must be recognised that the disapplication or modification of laws that are well-understood and, moreover, understood to be generally applicable, will not be consequence-free. Thirdly, and perhaps most critically, the regulators established to administer and enforce an applied law scheme must be accountable - preferably to a particular executive, and thus, a particular Parliament, and also via the courts and other scrutiny actors. Finally, at every stage, the overall complexity of the applied law scheme must not be forgotten, bearing in mind that the 'knowability' and 'accessibility' of the law are, ultimately, aspects of the rule of the law. ${ }^{61}$ Addressing these issues may come at a price in terms of the uniformity of the resulting applied law scheme. But is the price we pay for ignoring them any lower?

\footnotetext{
60 Note that Saunders, in particular, has argued that reference schemes, as opposed to other kinds of cooperative legislative schemes, represent a 'mechanism for collaboration that is compatible with the rest of the constitutional system'. C Saunders, 'Collaborative Federalism' (2002) 61 Australian Journal of Public Administration 75.

61 See generally Black-Clawson International Ltd v Papierwerke Waldhof-Aschaffenburg AG [1975] AC 591, 638 (Diplock LJ): 'The acceptance of the rule of law as a constitutional principle requires that a citizen, before committing himself to any course of action, should be able to know in advance what are the legal consequences that will flow from it' (emphasis added).
} 
This text taken from Law and Democracy: Contemporary questions, edited by Glenn Patmore and Kim Rubenstein, published 2014 by ANU Press, The Australian National University, Canberra, Australia. 